\title{
ORIGINAL
}

\section{Hemolysis of mammalian erythrocytes mediated by the myeloperoxidase, lactoperoxidase and saliva peroxidase systems}

\author{
Takeshi Odajima and Mihoko Onishi \\ Department of Oral Biochemistry, School of Dentistry, Health Sciences University of \\ Hokkaido, Tobetsu, Hokkaido 061-02, Japan
}

(Received on January 31, 1997 ; Accepted on May 19, 1997)

Key words : myeloperoxidase /lactoperoxidase / saliva peroxidase / hemolysis $/$ peroxidase $-\mathrm{H}_{2} \mathrm{O}_{2}-\mathrm{halide}$

\begin{abstract}
The hemolysis of horse, human and pig erythrocytes mediated by myeloperoxidase, lactoperoxidase and saliva peroxidase was studied using turbidimetry and microscopic analysis. The addition of myeloperoxidase, a hydrogen peroxide-generating system (glucose+glucose oxidase) and chloride or bromide caused the opaque suspensions of these mammalian erythrocytes to change into transparent (orange to yellowish green) solutions. Under the microscope, cells became dim circles and faded from the field of vision during the decrease in turbidity. Myeloperoxidase could be replaced by lactoperoxidase or saliva peroxidase in the system containing bromide, but not in that containing chloride. Hemolysis by these peroxidase systems was observed in the range of moderately acidic $\mathrm{pH}$, with the optimum $\mathrm{pH}$ values being between 5.0 and 5.5. The present study also showed that turbidimetry and microscopic analysis are useful in assessing hemolysis by the peroxidase-hydrogen peroxide-halide systems.
\end{abstract}

抄録：ミエロペルオキシダーゼ，ラクトペルオキシダーゼ，唾液ペルオキシダーゼが媒介するウマ，ヒト，フ 夕の赤血球の溶血反応を比濁分析および顕微鏡下の観察で明らかにした。赤血球䀣濁液にミエロペルオキシダー ゼ, 過酸化水素発生系（グルコーストグルコースオキシダーゼ）および塩素塩または臭素塩を加えると, 液は透 明化した。顕微鏡下での観察では, 濁度の低下と同時に赤血球は薄い輪状となり, 輪郭が次第に薄れ, 視野から 消えていく状態が観察された。ミエロペルオキシダーゼをラクトペルオキシダーゼあるいは唾液ペルオキシダー ゼに置き換えても，臭素塩の存在下では，同様の溶血反応が観察された。これらのぺルオキシダーゼ系による溶 血反応の至適 $\mathrm{pH}$ は，5.0 5.5 の弱酸性領域にみられた。本研究によって，比濁分析と顕微鏡観察を同時に行う ことはこれらのペルオキシダーゼ系による溶血反応を評価する有効な手段であることが証明された。

\section{Introduction}

A mixture of peroxidase, hydrogen peroxide and a halide or pseudohalide such as thiocyanate is known to constitute a potent oxidation system whose function depends on the oxidized halide or pseudohalide species. We previously reported that three animal peroxidases, together with hydrogen peroxide, peroxidize chloride, bromide, iodide and the pseudohalide thiocyanate in acidic solution: the peroxidation of chloride is catalyzed only by myeloperoxidase, while that of bromide, iodide and thiocyanate is catalyzed by myeloperoxidase, lactoperoxidase and saliva peroxidase $^{1)}$. Earlier investigators ${ }^{2 \sim 11}$ reported that animal peroxidases exhibit cytolytic activity toward several types of living eukaryote cells. We also reported that B-16 melanoma cells undergo cytolysis upon exposure to a system of myeloperoxidase, hydrogen peroxide (generated by glucose + glucose oxidase system) and chloride or bromide, or of lactoperoxidase, hydrogen peroxide and bromide, in the same $\mathrm{pH}$ range as that in which the halides are peroxidized by these peroxidases $^{12}$. The hemolysis of human erythrocytes 
in the presence of both chloride and iodide by myeloperoxidase at almost neutral $\mathrm{pH}$ has been reported by Klebanoff and Clark ${ }^{21}$, and the hemolysis of human erythrocytes in the presence of both chloride and iodide by lactoperoxidase has been reported by McFaul et al. ${ }^{3}$. There is, however, no comprehensive report on whether myeloperoxidase, lactoperoxidase and saliva peroxidase together with hydrogen peroxide and chloride, bromide or iodide hemolyze mammalian erythrocytes in the same $\mathrm{pH}$ range as that in which the peroxidases peroxidize these halides, or whether fluoride can also act as a co-factor in the hemolysis mediated by these peroxidase systems.

The aims of this study were (a) to determine whether the myeloperoxidase, lactoperoxidase and saliva peroxidase systems exhibit a hemolytic effect on animal erythrocytes, horse, human and pig erythrocytes, in the same $\mathrm{pH}$ range as that in which halides are peroxidized by these peroxidase systems : (b) to determine whether chloride, bromide and iodide are equally effective as a halide co-factor for this peroxidase-mediated hemolysis of these erythrocytes : (c) to determine whether fluoride, which is not peroxidized by the myeloperoxidase, lactoperoxidase and saliva peroxidase systems also acts as a co-factor for the hemolysis mediated by these peroxidases : (d) to examine whether the hemoglobin in hemolysate released from the erythrocytes hemolyzed by the peroxidase-hydrogen peroxide-halide system is usable as an index of hemolysis caused by the system, as reported by earlier investigators ${ }^{2,3)}$; and (e) to propose a continuous, real-time and visual method for determining the degree of hemolysis caused by these peroxidase systems.

In the present study, we used a continuous, realtime and visual method, turbidimetry together with microscopic analysis, to determine the extent of the hemolysis of erythrocytes caused by myeloperoxidase, lactoperoxidase and saliva peroxidase systems.

\section{Materials and Methods}

\section{Enzymes}

The peroxidases (EC 1.11.1.7) were prepared from polymorphonuclear leukocytes of normal pig blood (myeloperoxidase) ${ }^{13}$ ), from bovine milk (lactoperoxidase) ${ }^{14)}$ and from human parotid saliva (saliva peroxidase) ${ }^{15}$. The concentrations of myeloperoxidase, lactoperoxidase and saliva peroxidase were calculated on the basis of millimolar extinction coefficients of $95 \mathrm{mM}^{-1} \mathrm{~cm}^{-1}$ at $430 \mathrm{~nm}, 114$ $\mathrm{mM}^{-1} \mathrm{~cm}^{-1}$ at $412 \mathrm{~nm}$ and $114 \mathrm{mM}^{-1} \mathrm{~cm}^{-1}$ at $412 \mathrm{~nm}$, respectively. These peroxidase preparations typically exhibited R.Z. values of more than 0.85 and were previously confirmed to give a single band on polyacrylamide gel electrophoresis. Glucose oxidase (EC 1. 1. 3. 4) was purchased from Miles Laboratories Inc. (England).

\section{Preparation of erythrocytes}

Human erythrocytes were prepared from venous blood of healthy adult volunteers (male) using the method of Klebanoff and $\mathrm{Clark}^{2}$. The hematocrit value of the donors was in the normal range (44 to $45)$. Horse and pig erythrocytes were prepared from venous blood of normal animals containing an equal volume of autoclaved Alsever's solution, as follows. The blood sample was centrifuged for $5 \mathrm{~min}$ at $700 \times$ $g$ at $5^{\circ} \mathrm{C}$. The buffy coat and supernatant were removed and the erythrocytes were washed twice with cold $0.106 \mathrm{M}$ phosphate buffer ( $\mathrm{pH} 7.0$ ) and three times with cold $0.1 \mathrm{M}$ sodium sulfate solution. The erythrocytes were finally suspended in a small volume of $0.1 \mathrm{M}$ sodium sulfate solution and stored on ice until use. The hematocrit values of the donor horse and pig were 41 and 42 , respectively, each being with in normal range. These erythrocytes were prepared daily. All operations were performed under sterile conditions. The number of erythrocytes was counted by two methods, using a Thoma-Zeiss hemocytometer and a micro cell counter (Toa Medical Electronics, model Sysmex $_{\mathrm{TM}}$ F-800, Kobe).

\section{Estimation of hemolysis of erythrocytes}

To determine hemolysis, the change in turbidity of an erythrocyte suspension was examined using the method of McFaul et al. ${ }^{3,16)}$ with a modification, i. e., the decrease in turbidity (optical density) of the erythrocyte suspension at the wavelength of $540 \mathrm{~nm}$ was measured continuously. The turbidimetry was carried out with a Hitachi double beam spectrophotometer, type 200-20. The reaction mixture (final 
volume of $2.08 \mathrm{ml}$ ) used for turbidimetry was prepared by the successive addition of glucose, peroxidase (myeloperoxidase, lactoperoxidase or saliva peroxidase) and glucose oxidase to a horse, human or pig erythrocyte suspension $\left(2.5 \times 10^{7}\right.$ cells $\left./ \mathrm{m} l\right)$ in $25 \mathrm{mM}$ buffer solution containing sodium sulfate and halide (sodium chloride, potassium bromide, potassium iodide or potassium fluoride) in a quartz cuvette (10X $10 \times 45 \mathrm{~mm}$ ) at $25^{\circ} \mathrm{C}$. To prevent autolysis of the erythrocytes due to alterations in osmotic pressure, the erythrocyte suspension was prepared in an isotonic solution, of which the salt concentration was balanced with sodium sulfate. The concentration of each peroxidase in the present experiments was $50 \mathrm{nM}$. The reaction was always started by the final addition of glucose oxidase. The hydrogen peroxide-generating system (glucose + glucose oxidase) was chosen to provide a continuous and good supply of hydrogen peroxide, because hydrogen peroxide was rapidly decomposed by endogenous catalase in the erythrocytes. The supply of hydrogen peroxide was controlled at $3.8 \mu$ moles $\mathrm{m}^{-1} \mathrm{~min}^{-1}$ in the $\mathrm{pH}$ range of 4.5 to 8.5 at $25^{\circ} \mathrm{C}$ by adjustment of the concentration of glucose oxidase. The glucose concentration used throughout was $8 \mathrm{mM}$. The rate of supply of hydrogen peroxide was estimated from the extent of reduction of molecular oxygen by glucose in the presence of glucose oxidase in each $\mathrm{pH}$ buffer solution using an oxygen analyzer equipped with a YSI model 5331 oxygen electrode (Yellow Springs Instrument).

The changes in the population of erythrocytes accompanying hemolysis were observed using an Olympus microscope (type IMT-2) equipped with a differential interference apparatus. Photographs were taken with an Olympus camera (model OM-2) using Polaroid film (High Contrast PolaChrome $35 \mathrm{~mm}$ ). The microscopic observation was performed on an erythrocyte suspension in a small glass Petri dish at $25^{\circ} \mathrm{C}$. The residual erythrocytes were counted in photographs, which were enlarged 600 times, taken in randomly chosen fields of vision at regular time intervals.

\section{Preparation of hemolysates}

An aliquot of $5.0 \times 10^{7}$ cells $/ \mathrm{m} l$ of horse, human or pig erythrocytes was hemolyzed in distilled water by shaking gently for $5 \mathrm{~min}$ at $25^{\circ} \mathrm{C}$ and stored on ice until use. The operations were performed under sterile conditions. The state and amount of the hemoglobin released from the erythrocytes corresponding to $2.5 \times$ $10^{7}$ cells $/ \mathrm{m} l$ in $25 \mathrm{mM}$ buffer solution containing 0.09 $M$ sodium sulfate used in the present study were previously confirmed as follows. The hemoglobin in each hemolysate existed in the form of oxyhemoglobin, which accounted for up to $99 \%$ of hemoglobin, as estimated from the ratio of absorbance of the $\gamma$ band (Soret's band) and $\alpha$-band. The amounts of hemoglobin in the hemolysates corresponding to $2.5 \times$ $10^{7}$ cells $/ \mathrm{m} l$ of horse, human and pig erythrocytes were estimated to be $20 \mu \mathrm{M}, 19 \mu \mathrm{M}$ and $21 \mu \mathrm{M}$ on the basis of millimolar extinction coefficients of the light absorption peaks of the oxyhemoglobins, respectively. The $\varepsilon_{\mathrm{mm}}$-values of oxyhemoglobins used were : 124 at $413 \mathrm{~nm}$ ( $\gamma$-band), 15.2 at $541 \mathrm{~nm}(\alpha$-band) and 15.9 at $576 \mathrm{~nm}$ ( $\beta$-band) for horse ${ }^{17)} ; 131$ at $415 \mathrm{~nm}\left(\gamma^{-}\right.$ band), 14.4 at $542 \mathrm{~nm}$ ( $\alpha$-band) and 15.4 at $577 \mathrm{~nm}(\beta$ -band) for human ${ }^{17)}$; and 129 at $414 \mathrm{~nm}$ ( $\gamma$-band), 15.0 at $540 \mathrm{~nm}$ ( $\alpha$-band) and 15.6 at $576 \mathrm{~nm}$ ( $\beta$-band) for pig. The preparations of hemoglobin in each hemolysate of horse, human and pig erythrocytes used in the present study were previously confirmed to be stable for up to 24 hours on ice. It was ascertained that the oxyhemoglobin in the preparations was completely converted to deoxyhemoglobin by adding sodium hydrosulfite (Wako Chemical Industries, Osaka, Japan), and this deoxyhemoglobin was reconverted to oxyhemoglobin by bubbling oxygen gas (99.9\%, from Nippon Sanso, Tochigi, Japan). This conversion was used to measure the hemoglobin. The contribution of the optical density of hemoglobin at the wavelength of $540 \mathrm{~nm}$ to turbidity of the erythrocyte suspension was estimated to be at most $15 \%$. This contribution throughout the present study was neglected in comparison with the magnitude of the changes in turbidity.

Estimation of destruction of hemoglobin in hemolysates by the system consisting of peroxidase, glucose, glucose oxidase and halide

The extent of the destruction of hemoglobin in hemolysates caused by the peroxidase systems was estimated from the decrease in optical density (absorbance) of the hemoglobin at $540 \mathrm{~nm}$ using a Hitachi 
double wavelength-double beam spectrophotometer (type 557). The experiments were performed in a quartz cuvette $(10 \times 10 \times 45 \mathrm{~mm})$ at $25^{\circ} \mathrm{C}$. The reaction mixture was composed of hemolysate corresponding to that released from $2.5 \times 10^{7} / \mathrm{m} l$ erythrocytes, myeloperoxidase, sodium chloride (10 or $100 \mathrm{mM}), 4$ $\mathrm{mM}$ glucose, $0.28 \mathrm{U} / \mathrm{m} l$ glucose oxidase, $0.087 \mathrm{M}$ sodium sulfate $(0.08 \mathrm{M}$ sodium sulfate with $10 \mathrm{mM}$ sodium chloride and $0.02 \mathrm{M}$ sodium sulfate with 100 $\mathrm{mM}$ sodium chloride) and $16 \mathrm{mM}$ buffer, with the concentrations of the components used by Klebanoff and $\mathrm{Clark}^{2)}$, except that the concentration of myeloperoxidase was $50 \mathrm{nM}$.

\section{Reagents and Buffers}

Reagents were obtained from commercial sources in the highest available states of purity, unless otherwise stated. The buffers used were acetate (acetic acid/sodium acetate) for $\mathrm{pH} 4.5-6.0$, phosphate (potassium phosphate, monobasic/sodium phosphate, dibasic) for 6.0-8.0 and borate (boric acid/sodium carbonate) for $\mathrm{pH} 8.0-8.5$.

\section{Results}

On addition of myeloperoxidase, a hydrogen peroxide-generating system (glucose+glucose oxidase) and chloride or bromide to horse, human or pig erythrocyte suspension in a moderately acidic buffer solution, the turbidity of the reaction solution decreased with time after a remarkable lag time. A typical result is shown in Figure 1A. Accompanying the decrease in turbidity, the opaque suspension became a transparent orange to yellowish green solution. Under the microscope, cells became dim circles and faded from the field of vision, and the cell population decreased. From these findings, we concluded that the erythrocytes were hemolyzed by the system consisting of myeloperoxidase, hydrogen peroxide released from a hydrogen peroxide-generating system (glucose + glucose oxidase) and chloride or bromide. Figure 1B shows plots of the number of residual erythrocytes counted from the photographs taken at regular intervals for the same system as that in Figure 1A. Myeloperoxidase could be replaced by lactoperoxidase or saliva peroxidase in the system containing

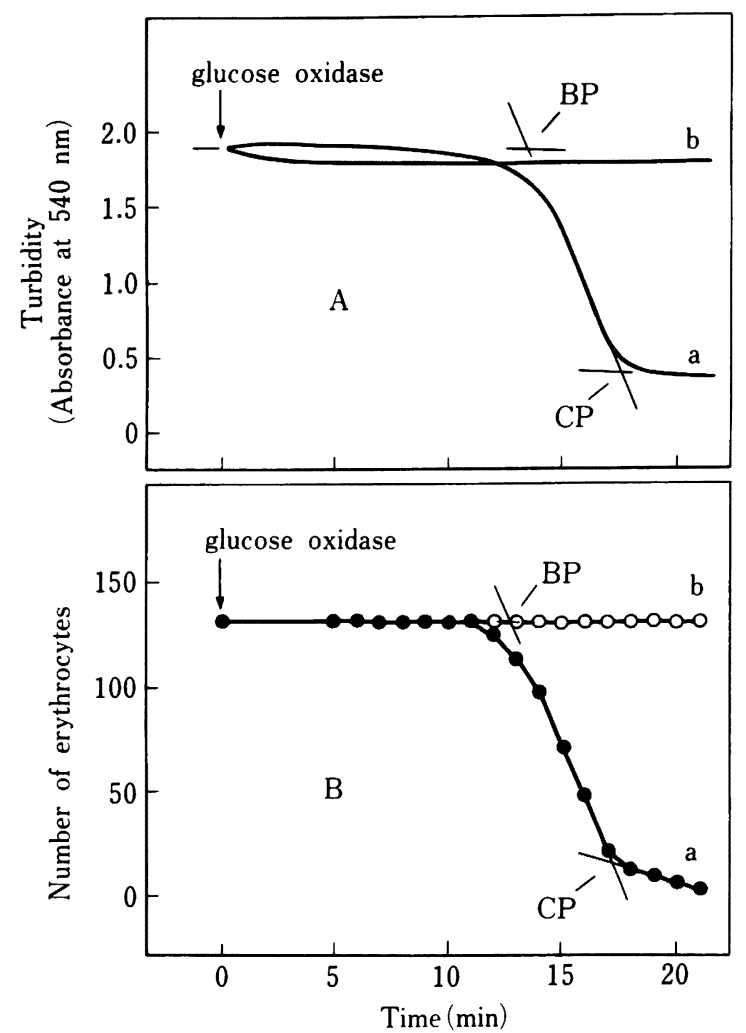

Fig. 1 Changes in turbidity and cell population of erythrocyte suspension caused by myeloperoxidase, a hydrogen peroxide-generating system (glucose+ glucose oxidase) and chloride.

A. Change in tubidity. Curve (a): The reaction was started by addition of $10 \mu l$ of glucose oxidase solution to the reaction solution containing $2.5 \times 10^{7} / \mathrm{m} l$ horse erythrocytes, $20 \mathrm{mM}$ sodium chloride, $8 \mathrm{mM}$ glucose, $50 \mathrm{nM}$ myeloperoxidase and $0.077 \mathrm{M}$ sodium sulfate in $25 \mathrm{mM}$ acetate buffer solution ( $\mathrm{pH} 5.5$ ). Curve (b): As (a), except that sodium chloride was omitted and the concentration of sodium sulfate was $0.09 \mathrm{M}$.

B. Change in cell population observed under the microscope. Curve (a): The number of residual erythrocytes was counted in photographs of randomly chosen fields of vision taken at 1-min intervals. The datum at zero time was obtained from a photograph taken before the addition of glucose oxidase. The conditions were the same as those in the experiment A. Points are the means of ten determinations, rounded to the nearest whole number. Curve (b) : As (a), but with chloride omitted.

$\mathrm{BP}$ and $\mathrm{CP}$ show the beginning point and completion point of the steep reaction, respectively. 
bromide, but not in that containing chloride. In control systems from which any one of the components, i.e., the halide, peroxidase, glucose or glucose oxidase, was omitted, the turbidity did not appreciably decrease and the erythrocyte population remained unchanged. The action of peroxidase was shown to be related to its enzymatic activity by the fact that turbidity was unchanged when myeloperoxidase, lactoperoxidase or saliva peroxidase was replaced by the respective heated peroxidase (at $85^{\circ} \mathrm{C}$ for $60 \mathrm{sec}$ ). At the plateau of turbidity decrease in these experiments, about 10 to $15 \%$ of the initial turbidity (optical density) remained, possibly due to hemolysate, even though no remaining erythrocytes were observed under the microscope. The optimal concentrations of chloride and bromide for the reaction of myeloperoxidase, lactoperoxidase or saliva peroxidase with horse erythrocytes were determined from the rate of the change in turbidity, $\Delta \mathrm{A}_{540} / \Delta \mathrm{t}$, estimated from the tangential line to the time courses of the steep decrease in turbidity: 15 to $20 \mathrm{mM}$ chloride in the myeloperoxidase system and 0.5 to $1 \mathrm{mM}$ bromide in all peroxidase systems (Fig. 2). At higher halide concentrations, the rates gradually decreased. Human and pig erythrocytes produced essentially the same results as horse erythrocytes (data not shown). The effect of $\mathrm{pH}$ was examined in the range of 4.5 to 8.5 , and the decrease in turbidity was observed in a restricted range of moderately acidic $\mathrm{pH}$, as in Figure 3. The optimum $\mathrm{pH}$ values, giving the fastest rate, were between 5.0 and 5.5 (Table 1). The times of the beginning point and completion point of steep reaction in the time course of the decrease of turbidity were in good agreement with the respective times in the time course of the decrease in erythrocyte cell population (Table 1). From this we concluded that the decrease
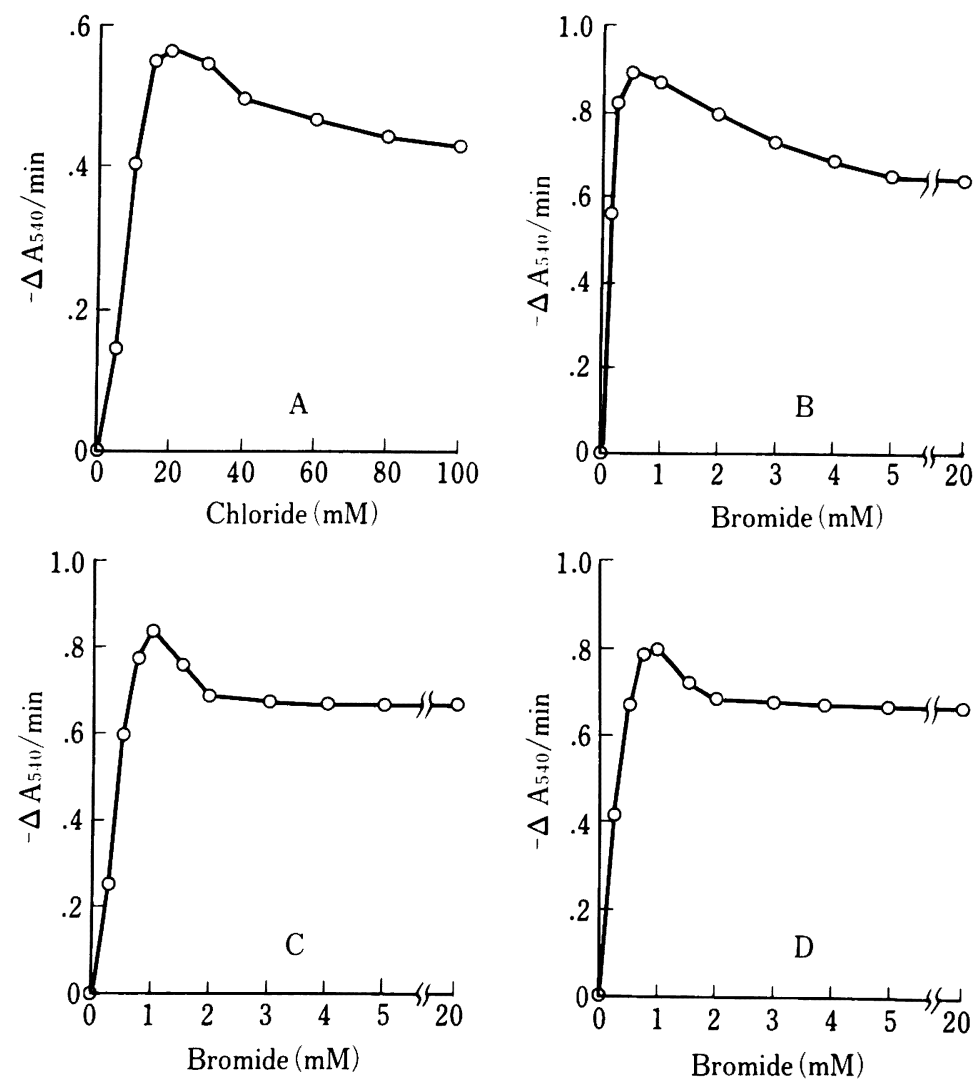

Fig. 2 Effect of halide concentration on the rate of change of the decrease in turbidity of horse erythrocyte suspensions caused by the peroxidase systems.

A : Chloride with myeloperoxidase. B : Bromide with myeloperoxidase. $\mathrm{C}:$ Bromide with lactoperoxidase. D: Bromide with saliva peroxidase. Conditions were as in Figure 1, except that myeloperoxidase was replaced by lactoperoxidase or saliva peroxidase, $\mathrm{pH}$ of buffer solution was 5.5, and the concentration of sodium sulfate was varied. At $25^{\circ} \mathrm{C}$. 
in turbidity of the erythrocyte suspension reflected hemolysis. Table 1 shows that the times observed in turbidimetry were consistent with those estimated from the microscopic analysis, and that the three kinds of erythrocytes were similarly susceptible to hemolysis by the same peroxidase systems. Thus, the horse, human and pig erythrocytes were equally hemolyzed by the myeloperoxidase system in the presence of chloride, and the myeloperoxidase, lactoperoxidase or saliva peroxidase systems in the presence of bromide. Fluoride did not cause hemolysis in any of these peroxidase systems. In the reaction system containing iodide at higher than $0.2 \mathrm{mM}$, change in turbidity was unmeasurable due to interference by a colored by-product, $\mathrm{I}_{3}{ }^{-}$, formed from a peroxidized product of iodide ${ }^{18)}$ which has a broad absorption peak in the visible region. Under the microscope, it was observed that the myeloperoxidase, lactoperoxidase and saliva peroxidase systems containing the hydrogen peroxide-generating system and $0.5 \mathrm{mM}$ iodide hemolyzed equally the horse, human and pig erythrocytes at moderately acidic $\mathrm{pH}$, the optimum $\mathrm{pH}$ values being between 5.0 and 5.5 . Thiocyanate also caused hemolysis, which was confirmed by the decrease in turbidity of horse, human and pig erythrocyte suspensions in all of the myeloperoxidase, lactoperoxidase and saliva peroxidase systems (the result for saliva peroxidase is shown in Fig. 4) and by observation under the microscope.

The reaction of hemoglobin in the hemolysate with the peroxidase systems was examined, for example, as in Figure 5. The results showed that the optical density (absorbance) of the hemoglobin at $540 \mathrm{~nm}$ in the hemolysate solution of horse, human or pig erythrocytes, containing an equivalent amount of hemoglobin to that released from $2.5 \times 10^{7}$ cells $/ \mathrm{m} l$ erythrocytes, was decreased by a complete system comprised of myeloperoxidase, hydrogen peroxide-generating system (glucose + glucose oxidase) and chloride. Myeloperoxidase could be replaced by lactoperoxidase $(50 \mathrm{nM})$ or saliva peroxidase $(50 \mathrm{nM})$ in the system containing bromide ( 0.5 to $20 \mathrm{mM}$ ), but not in that containing chloride. The effect of $\mathrm{pH}$ was examined in the range of 4.5 to 8.5 . Each reaction was observed in the range of moderately acidic $\mathrm{pH}$, the

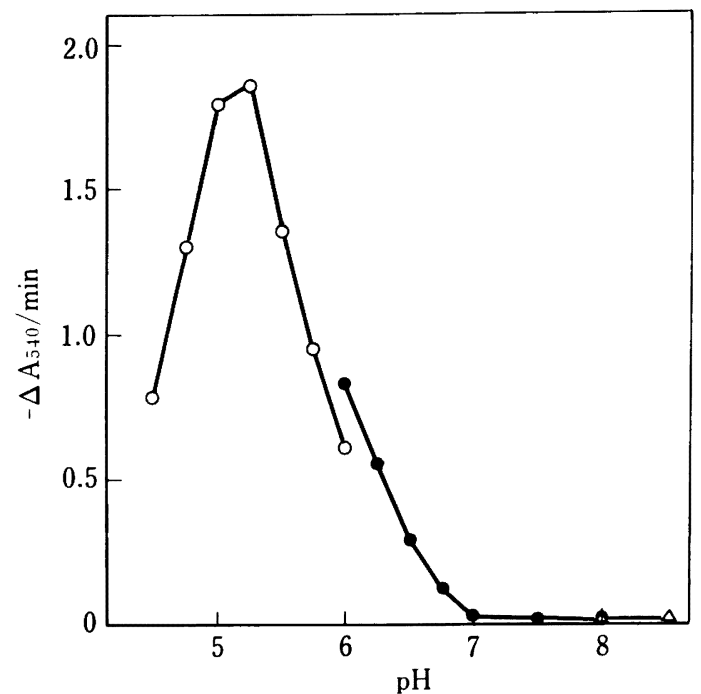

Fig. 3 Effect of $\mathrm{pH}$ on the rate of the decrease in turbidity of erythrocyte suspension caused by the myeloperoxidase system.

$(-\bigcirc-\bigcirc-)$, acetate buffer: (-O-O-), phosphate buffer : and $(-\triangle-\triangle-)$, borate buffer. Other conditions as indicated in Figure 1.

optimum $\mathrm{pH}$ with the fastest rate being between 5.0 and 5.5 , as in the $\mathrm{pH}$-dependence observed by turbidimetry. A similar reaction was caused by the hydrogen peroxide-generating system itself, although the reaction rate was slower than that of the complete system (inset of Fig. 5), and the reaction rate gradually increased without exhibiting a peak as the $\mathrm{pH}$ was lowered. After the reaction with the complete peroxidase systems or the hydrogen peroxide-generating system, the hemoglobin was completely devoid of the $\alpha$-band and $\beta$-band characterizing oxyhemoglobin. The products of these reactions were not convertable to deoxyhemoglobin by addition of excess sodium hydrosulfite, nor to oxyhemoglobin by subsequent bubbling of oxygen gas into the solution. The spectral profiles of the products of reaction with the complete system and the hydrogen peroxide-generating system were not the same (curves b and c in Fig. 5 ), and neither spectrum was consistent with that of methemoglobin. These findings clearly indicate that the hemoglobin itself in the hemolysate was destroyed by the hydrogen peroxide released from the hydrogen peroxide-generating system, and more efficiently by the peroxidase-hydrogen peroxide-halide system. The 
Table 1 The beginning point (BP) and completion point (CP) of the steep reaction estimated from the time courses of the decrease in turbidity of erythrocyte suspensions (A) and the numbers of residual erythrocytes, counted in photographs taken at 1-min intervals under the microscope (B), in the reaction of erythrocytes with the peroxidase systems

\begin{tabular}{|c|c|c|c|c|c|c|c|}
\hline \multicolumn{4}{|c|}{ Systems } & \multicolumn{2}{|c|}{ A (by turbidimetry) } & \multicolumn{2}{|c|}{ B (by microscope) } \\
\hline Enzyme & $\begin{array}{l}\text { Halide } \\
(\mathrm{mM})\end{array}$ & $\begin{array}{l}\text { Erythro- } \\
\text { cyte }\end{array}$ & $\mathrm{pH}^{*}$ & $\underset{\substack { \text { BP } \\
(\mathrm{min}) \\
\begin{subarray}{c}{\mathrm{M}=\mathrm{n}=\mathrm{S} . \\
\text {. }{ \text { BP } \\
( \mathrm { min } ) \\
\begin{subarray} { c } { \mathrm { M } = \mathrm { n } = \mathrm { S } . \\
\text { . } } }\end{subarray}}{ }$ & $\underset{\substack{C P \\
(\mathrm{~min})}}{\text { Mean } \pm \mathrm{S}=10)}$. & $\underset{\substack{\text { BP } \\
(\mathrm{min}) \\
\text { Mean } \mathrm{n}=10)}}{\text { E. E. }}$ & 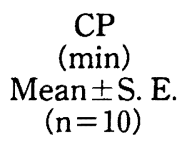 \\
\hline MPO & $\mathrm{Cl}(20)$ & Horse & 5.5 & $13.6 \pm 0.20$ & $17.2 \pm 0.20$ & $13.0 \pm 0.21$ & $17.3 \pm 0.15$ \\
\hline MPO & $\mathrm{Cl}(20)$ & Human & 5.4 & $13.5 \pm 0.19$ & $17.2 \pm 0.23$ & $13.1 \pm 0.30$ & $17.4 \pm 0.30$ \\
\hline MPO & $\mathrm{Cl}(20)$ & Pig & 5.4 & $13.4 \pm 0.26$ & $17.4 \pm 0.30$ & $13.0 \pm 0.24$ & $17.2 \pm 0.28$ \\
\hline MPO & $\mathrm{Br}(1)$ & Horse & 5.5 & $4.2 \pm 0.15$ & $9.6 \pm 0.18$ & $4.4 \pm 0.15$ & $9.4 \pm 0.16$ \\
\hline MPO & $\mathrm{Br}(1)$ & Human & 5.3 & $4.3 \pm 0.13$ & $9.2 \pm 0.15$ & $4.2 \pm 0.17$ & $9.1 \pm 0.19$ \\
\hline MPO & $\mathrm{Br}(1)$ & Pig & 5.5 & $4.5 \pm 0.16$ & $9.5 \pm 0.12$ & $4.3 \pm 0.18$ & $9.3 \pm 0.17$ \\
\hline LPO & $\mathrm{Br}(1)$ & Horse & 5.0 & $4.4 \pm 0.13$ & $9.3 \pm 0.15$ & $4.3 \pm 0.16$ & $9.2 \pm 0.18$ \\
\hline LPO & $\mathrm{Br}(1)$ & Human & 5.1 & $4.3 \pm 0.15$ & $9.1 \pm 0.12$ & $4.1 \pm 0.11$ & $9.0 \pm 0.15$ \\
\hline LPO & $\mathrm{Br}(1)$ & Pig & 5.0 & $4.5 \pm 0.14$ & $9.3 \pm 0.17$ & $4.3 \pm 0.15$ & $9.1 \pm 0.16$ \\
\hline SPO & $\mathrm{Br}(1)$ & Horse & 5.2 & $4.6 \pm 0.16$ & $9.4 \pm 0.18$ & $4.4 \pm 0.18$ & $9.2 \pm 0.13$ \\
\hline SPO & $\mathrm{Br}(1)$ & Human & 5.0 & $4.5 \pm 0.12$ & $9.3 \pm 0.15$ & $4.3 \pm 0.17$ & $9.0 \pm 0.15$ \\
\hline SPO & $\mathrm{Br}(1)$ & Pig & 5.2 & $4.7 \pm 0.18$ & $9.7 \pm 0.16$ & $4.5 \pm 0.13$ & $9.4 \pm 0.18$ \\
\hline
\end{tabular}

$\mathrm{BP}$ and $\mathrm{CP}$ are the points of intersection of tangential lines to the time course of the steep reaction with, respectively, linear extensions of the time courses before and after the steep reaction, as shown in Fig. 1. The conditions were the same as those in Fig. 1, except that horse erythrocytes were replaced by human or pig erythrocytes and myeloperoxidase was replaced by lactoperoxidase or saliva peroxidase in the system containing bromide. The experiments were performed at the optimal $\mathrm{pHs}^{*}$, which were obtained by turbidimetry. Abbreviations: MPO, myeloperoxidase : LPO, lactoperoxidase : SPO, saliva peroxidase.

hemoglobin in the hemolysate from which ghosts had been removed by centrifugation at $20,000 \times g$ for 30 $\min$ at $4^{\circ} \mathrm{C}$ was also destroyed in the same manner. The destruction of hemoglobin in hemolysate observed was similarly observed under the conditions for determination of hemolysis. From these results, we concluded that it is impossible for hemoglobin in hemolysate to be used as a precise index of hemolysis caused by the peroxidase-hydrogen peroxide-halide system.

\section{Discussion}

By using turbidimetry together with microscopic analysis, the hemolysis of three kinds of mammalian erythrocytes caused by the myeloperoxidase, lactoperoxidase and saliva peroxidase systems was investigated. There were good coincidences in the $\mathrm{pH}$ optima and the specificity for the kinds of peroxidase or halide between the hemolysis mediated by the systems of these three peroxidases, hydrogen peroxide and halides observed in the present study, and the peroxidation of halides themselves by these peroxidase ${ }^{1)}$. These findings suggested that the peroxidation of halides is the rate-limiting step in the hemolysis mediated by these peroxidase-hydrogen peroxidehalide systems. We considered the mechanism of the hemolysis caused by the peroxidase systems to be as in the processes drawn in Figure 6. The products of halide peroxidized by peroxidase and/or their byproducts may attack the erythrocytes resulting in their hemolysis as reported previously ${ }^{1)}$. The similar reactivity of the pseudohalide thiocyanate to that of halide indicates that it might replace the halide, bromide or iodide in vivo, especially in the saliva peroxidase system ${ }^{19,20)}$. The distribution of chloride, bro- 


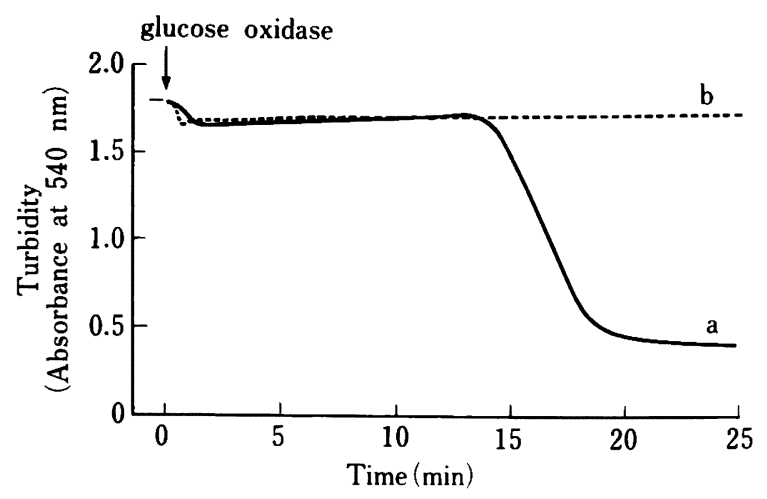

Fig. 4 Change in turbidity of erythrocyte suspension caused by saliva peroxidase, a hydrogen peroxidegenerating system (glucose + glucose oxidase) and thiocyanate.

Curve a : complete system. Curve b : as (a) except that thiocyanate was omitted. The reaction was started by addition of $10 \mu l$ of glucose oxidase solution to the reaction solution containing $2.5 \times 10^{7} / \mathrm{m} l$ horse erythrocytes, 2 $\mathrm{mM}$ sodium thiocyanate, $8 \mathrm{mM}$ glucose, $190 \mathrm{nM}$ saliva peroxidase and $0.09 \mathrm{M}$ sodium sulfate in $25 \mathrm{mM}$ acetate buffer solution ( $\mathrm{pH} 4.5)$.

mide, iodide and thiocyanate in vivo, especially in body fluids such as serum, breast milk and saliva has been reported to be maximally as follows : 98 to 107 mM chloride, 49 to $90.7 \mu \mathrm{M}$ bromide, 0.25 to $0.57 \mu \mathrm{M}$ iodide, 10 to $166 \mu \mathrm{M}$ thiocyanate (non-smoker) and 18 to $110 \mu \mathrm{M}$ thiocyanate (smoker) in blood ; 26.2 to 39.7 $\mathrm{mM}$ chloride and 0.331 to $0.78 \mathrm{mM}$ iodide in cow's milk ; 6.5 to $42.9 \mathrm{mM}$ chloride, 2.5 to $13 \mu \mathrm{M}$ bromide, 0.41 to $6.55 \mathrm{mM}$ thiocyanate (unstimulated, nonsmoker) and 1.2 to $12.2 \mathrm{mM}$ thiocyanate (unstimulated, smoker) in whole saliva ${ }^{21,22)}$. From this study and the previous report ${ }^{11}$, these concentrations of halide and thiocyanate were in most cases judged to be sufficient to cause hemolysis in vivo. Briefly, the chloride in vivo may be sufficient for the myeloperoxidase system. The amount of bromide in blood should be almost sufficient for the three kinds of peroxidases, myeloperoxidase, lactoperoxidase and saliva peroxidase. The amount of iodide in milk and blood should be sufficient for the myeloperoxidase, lactoperoxidase and saliva peroxidase systems, but iodide in vivo may not act as a co-facter for these peroxidase systems, since it probably contributes to the synthesis of thyroid hormone ${ }^{23}$. The thiocyanate is probably suffi-

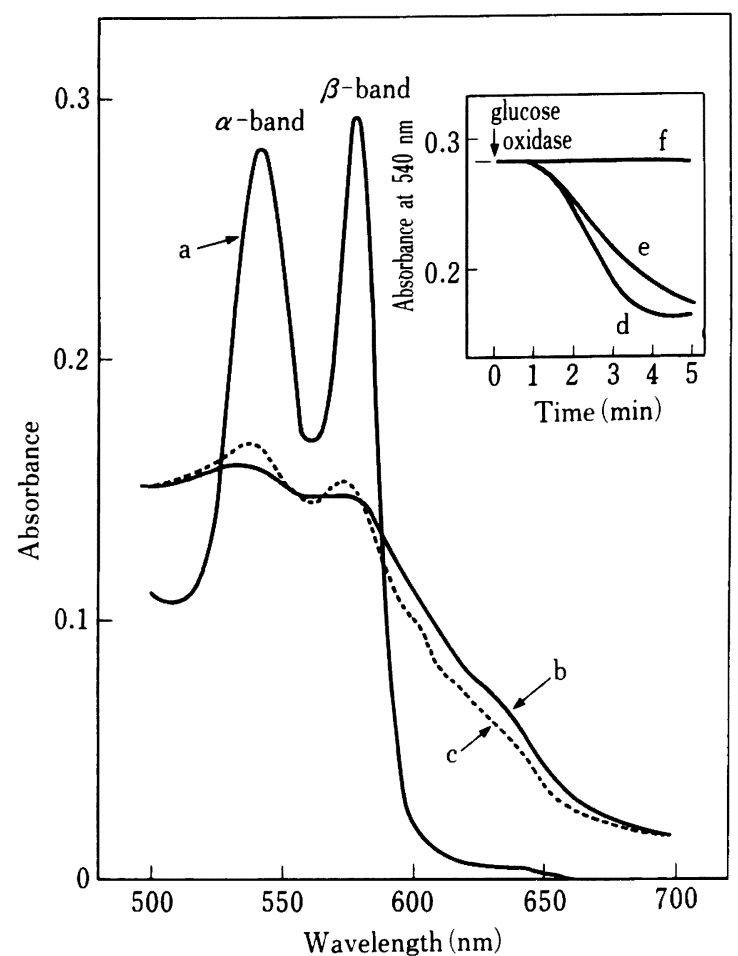

Fig. 5 Destruction of hemoglobin in hemolysate caused by the complete system comprised of myeloperoxidase, hydrogen peroxide-generating system (glucose +glucose oxidase) and chloride, and the hydrogen peroxide-generating system (glucose + glucose oxidase)

Curve (a) [solution (a) : Horse hemolysate corresponding to the amount of hemoglobin released from $2.5 \times 10^{7}$ cells $/ \mathrm{m} l$ erythrocytes in $16 \mathrm{mM}$ acetate buffer solution (pH 5.5) containing $0.02 \mathrm{M}$ sodium sulfate and $100 \mathrm{mM}$ sodium chloride. Curve (b) was recorded $5 \mathrm{~min}$ after the successive additions of $50 \mathrm{nM}$ myeloperoxidase, $4 \mathrm{mM}$ glucose and $0.28 \mathrm{U} / \mathrm{m} l$ glucose oxidase to solution (a). Curve (c) was recorded $5 \mathrm{~min}$ after the additions of $4 \mathrm{mM}$ glucose and $0.28 \mathrm{U} / \mathrm{m} l$ glucose oxidase to solution (a).

Inset. Change in absorbance at $540 \mathrm{~nm}$ of hemolysate caused by the complete system comprised of myeloperoxidase, hydrogen peroxide-generating system (glucose + glucose oxidase) and chloride, and the hydrogen peroxide -generating system (glucose+glucose oxidase).

Curve (d) : As (b), except that the reaction was started by addition of glucose oxidase solution. Curve (e): As (c) except that the reaction was started by the addition of glucose oxidase solution. Curve (f) : As (b), except that glucose was omitted and the reaction was started by the addition of glucose oxidase solution. These experiments were done at $25^{\circ} \mathrm{C}$. 


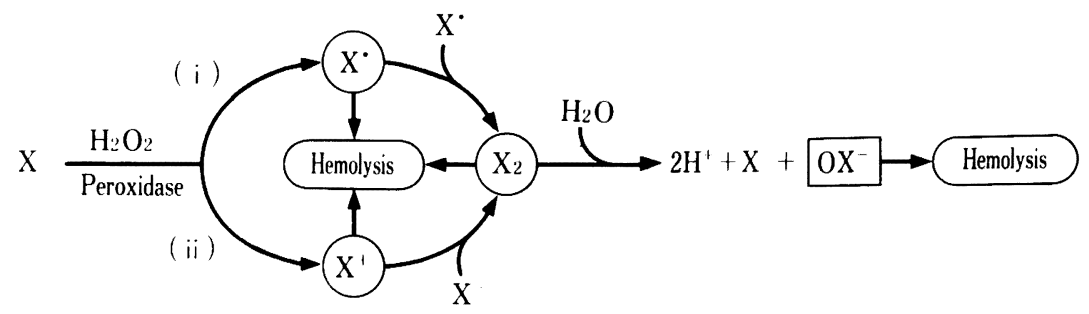

Fig. 6 The processes of hemolysis caused by the peroxidase-hydrogen peroxide-halide system. The halide anion, free radical of halide, halide cation, molecular halide and hypohalite were termed $\mathrm{X}^{-}$, $\mathrm{X}^{\bullet}, \mathrm{X}^{+}, \mathrm{X}_{2}$ and $\mathrm{OX}^{-}$, respectively. ( $\mathrm{i}$ ), one electron oxidation pathway: (ii), two electron oxidation pathway ${ }^{1}$.

cient for all myeloperoxidase, lactoperoxidase and saliva peroxidase systems, but it may contribute exclusively to formation of the oxidation system with saliva peroxidase. The lag before the start of hemolysis observed in the tubidimetry and microscopic observation might reflect the period during which the erythrocyte membrane, comprising a thick, solid macromolecular layer, was lysed inwards from the surface by the peroxidase system.

It is worth noting that the optimum $\mathrm{pH}$ range (5.0 to 5.5) observed here lies within the limits of the $\mathrm{pH}$ changes, from neutral or slightly acidic to moderately acidic ( $\mathrm{pH} 4.7$ to 5.2), which occur in the cytoplasm of leukocytes during phagocytosis, as reported by Pavlov and Solov'ev ${ }^{24)}$. This parallelism suggests that myeloperoxidase localized in phagolytic leukocytes, namely, neutrophils, naturally acts at acidic $\mathrm{pH}$ in the presence of a halide ion. The myeloperoxidase system in neutrophils may scavenge injured and/or diseased erythrocytes. The $\mathrm{pH}$ of secreted milk containing lactoperoxidase and of secreted saliva containing saliva peroxidase normally lies within the range of nearly neutral to slightly acidic ${ }^{25,26)}$. Under these $\mathrm{pH}$ conditions, the lactoperoxidase and saliva peroxidase are unlikely to depend upon the presence of a halide ion: possibly these peroxidases act as a part of the self-defense systems that operate when the local environment of a breast or oral cavity becomes acidified on stimulation by xenobiotics.

In conclusion, turbidimetry and microscopic analysis were successfully used to determine quantitatively the hemolysis of erythrocytes caused by the myeloperoxidase, lactoperoxidase and saliva perox- idase systems, which are dependent upon a halide ion. Consequently, it was observed that hemolysis mediated by these peroxidase systems containing halide occurred significantly at moderately acidic $\mathrm{pH}$. This study might provide an indicator of the cytotoxicity caused by the peroxidase-hydrogen peroxide-halide system.

\section{Acknowledgments}

The authors wish to thank Professor Shingo Nakamura, Hirosaki University, Hirosaki, for his generous gift of lactoperoxidase. The authors also wish to thank Sapporo Research Laboratory, Snow Brand Milk Products Co., Ltd., Sapporo, for the generous gift of cow's milk as the source of lactoperoxidase, and Mr. Hidetoshi Ishikawa and Mr. Masakazu Horikawa, of this laboratory, their helpful support in the preparation of lactoperoxidase.

\section{References}

1) Onishi, M., Nakamura, S. and Odajima, T.: A direct observation of the peroxidase catalyzed oxidation of halide and thiocyanate ions. Jpn. J. Oral Biol. 30 : 334 339, 1988.

2) Klebanoff, S. J. and Clark, R. A. : Hemolysis and iodination of erythrocyte components by a myeloperoxidase-mediated system. Blond 45 : 699 707, 1975.

3) McFaul, S. J., Stuyt, E. L. and Everse, J. : Observation on the cytolytic activity of lactoperoxidase using a continuous assay. Proc. Soc. Exp. Biol. Med. 179 : 331 337, 1985. 
4) Clark, R. A., Klebanoff, S. J., Einstein, A. B. and Fefer, A. : Peroxidase $-\mathrm{H}_{2} \mathrm{O}_{2}$-halide system : Cytotoxic effect on mammalian tumor cells. Blood 45: 161 170, 1975.

5) Clark, R. A. and Klebanoff, S. J. : Neutrophilmediated tumor cell cytotoxicity: Role of the peroxidase system. J. Exp. Med. $141: 1442 \sim 1447$, 1975.

6) Clark, R. A. and Klebanoff, S. J. : Role of the myeloperoxidase $-\mathrm{H}_{2} \mathrm{O}_{2}$-halide system in concanavalin A-induced tumor cell killing by human neutrophils. J. Immunol. $122: 2605 \sim 2610,1979$.

7) Nathan, C. F., Brukner, L. H., Silverstein, S. C. and Cohn, Z. A. : Extracellular cytolysis by activated macrophages and granulocytes. I. Phamacologic triggering of effector cells and the release of hydrogen peroxide. J. Exp. Med. 149 : 84 99, 1979.

8) Nathan, C.F., Arrick, B. A., Murray, H.W., DeSantis, N. M. and Cohn, Z. A. : Tumor cell anti -oxidant defenses. Inhibition of the glutathione redox cycle enhances macrophage-mediated cytolysis. J. Exp. Med. 153: 766 782, 1980.

9) Philpott, G. W., Kulczycki, A. Jr., Grass, E. H. and Parker, C. W. : Selective binding and cytotoxicity of rat basophilic leukemia cells (RBL-1) with immunoglobulin E-biotin and avidin-glucose oxidase conjugates. J. Immunol. 125: 1201 1209, 1980.

10) Nathan, C. F. and Cohn, Z. A. : Antitumor effects of hydrogen peroxide in vivo. J. Exp. Med. 154 : 1539 1553, 1981.

11) Mavier, P. and Edgington, T.S.: Human monocyte-mediated tumor cytotoxicity. I. Demonstration of an oxygen-dependent myeloperoxidase-independent mechanism. J. Immunol. 132 : 1980 1986, 1984

12) Odajima, T., Onishi, M., Hayama, E., Motoji, N., Momose, Y. and Shigematsu, A. : Cytolysis of B16 melanoma tumor cells mediated by the myeloperoxidase and lactoperoxidase systems. Biol. Chem. 377 : 689 693, 1996.

13) Odajima, T.: Myeloperoxidase of the leukocyte of normal blood. Nature of the prosthetic group of myeloperoxidase. J. Biochem. 87 : 379 391, 1980.

14) Morrison, M. and Hultquist, E. D. : Lactoperox idase. II. Isolation. J. Biol. Chem. 238: 2847 $\sim 2849,1963$.
15) Iwamoto, Y., Nakamura, R., Watanabe, T. and Tsunemitsu, A. : Heterogeneity of peroxidase related to antibacterial activity in human parotid saliva. J. Dent. Res. 51 : 503 508, 1972.

16) McFaul, S. J., Lin, H. and Everse, J. : The mechanism of peroxidase-mediated cytotoxicity. I. Comparison of horseradish peroxidase and lactoperoxidase. Proc. Soc. Exp. Biol. Med. 183 : 244 249, 1986.

17) Imai, K. : Heme-containing oxygen carriers. In : Metalloproteins. (Edited by Otsuka, S. and Yamanaka, T.), pp. 115 126, Elsevier, Amsterdam, 1988.

18) Odajima, T., Onishi, M. and Sato, N. : Oxidative destruction of the porphyrin derivatives and hemoproteins by the myeloperoxidase-hydrogen peroxide-chloride system. Jpn. J. Oral Biol. 24 : 243 248, 1982.

19) Thomas, E. L. : Products of lactoperoxidasecatalyzed oxidation of thiocyanate and halides. In: The lactoperoxidase system. (Edited by Pruitt, K. M. and Tenovuo, J. O.), pp. 31 53, Marcel Dekker Inc. New York, 1985.

20) Tenovuo, J. and Pruitt, K. M. : Relationship of the human salivary peroxidase system to oral health. J. Oral Pathol. $13: 573 \sim 584,1984$.

21) In: Geigy scientific tables. (Edited by Lentner, C.), vol. 1, pp. 114 216, Ciba-Geigy, Basle, Switzerland, 1981.

22) In: Geigy scientific tables. (Edited by Lentner, C.), vol. 3, pp. $78 \sim 89$, Ciba-Geigy, Basle, Switzerland, 1984.

23) Virion, A., Courtin, F., Deme, D., Michot, J. L., Kaniewski, J. and Pommier, J. : Spectral characteristics and catalytic properties of thyroid peroxidase $-\mathrm{H}_{2} \mathrm{O}_{2}$ compounds in the iodination and coupling reactions. Arch. Biochem. Biophys. 242:41 $\sim 47,1985$.

24) Pavlov, E. P. and Solov'ev, V. N. : pH changes of cytoplasm in phagocytosis of microorganisms stained with indicator dyes. Byull. Eksp. Biol. Med. 63: 78 81, 1967.

25) Flick, A. L. : Acid content of common beverages. Am. J. Dig. Dis. $15: 317 \sim 320,1970$.

26) Köstlin, A. and Rauch, S. : Zur Chemie des Ruhespeichels einzelner Speicheldrüsen. Helv. Med. Acta 24: 600 621, 1957. 